\title{
African Generation Y Students' Attitudes towards Personal Financial Planning
}

\author{
Marko van Deventer
}

North West University (Vaal Triangle Campus)

Email:21852898@nwu.ac.za

Natasha de Klerk PhD.

North West University (Vaal Triangle Campus)

Email: Natasha.deKlerk@nwu.ac.za

\section{Ayesha Lian Bevan-Dye PhD.}

North West University (Vaal Triangle Campus)

Email: Ayesha.Bevandye@nwu.ac.za

\section{Doi:10.5901/mjss.2014.v5n21p111}

\section{Abstract}

\begin{abstract}
Personal financial satisfaction arises from the ability to manage financial resources effectively. Individuals today face great challenges in managing their finances due to increased exposure to marketing activities, stemming from increased competition for consumers' money. However, even though various business courses comprise financial management content that focuses on the importance of managing and maximising wealth, students express little concern about their financial status, future wealth and retirement planning, This article reports on a study conducted in South Africa to determine African Generation $Y$ students' attitudes towards personal financial planning. The South African Generation Y cohort, defined as individuals born between 1986 and 2005, accounted for an estimated 38 percent of the country's population in 2013. In terms of race, the African portion of this cohort accounted for approximately 83 percent of this cohort and 32 percent of the total South African population. Therefore, the significant size of the African Generation Y market makes them salient to industry professionals, including financial institutions and those involved in financial management, especially in financial planning. Despite the importance of this market segment, their consumer behaviour remains under researched in general, specifically concerning their attitudes towards personal financial planning. In order to address this shortfall in the literature, a structured, selfadministered questionnaire was used to gather data on personal financial planning attitudes from a non-probability convenience sample of 500 African Generation Y students across two South African public higher education institutions' campuses located in the Gauteng province. The collected data was analysed using t-tests. According to the results, African Generation Y students have a significant positive attitude towards personal financial planning. This article concludes with recommendations for financial institutions, including banks, insurance- and investment companies regarding effective ways to convey financial knowledge and product information to deliver improved financial service to this segment.
\end{abstract}

Keywords: Personal financial management; personal financial planning; South Africa; Generation Y students

\section{Introduction}

The effective and efficient management of personal finances is critical for everyone (Chinen \& Endo, 2012), particularly in a world where uncertainties prevail (Mazzucato, Lowe, Shipman \& Trigg, 2010). Owing to continuous change, individuals are frequently confronted with new financial challenges, which, ultimately, culminate in uncertainties concerning their financial position and future financial well-being (Swart, 2012). Having a low level of debt, an active savings account and a retirement plan, as well as following an expenditure plan, will lead to financial wellness, which demonstrates an active state of financial wealth (Rutherford \& Fox, 2010; Chinen \& Endo, 2012). A comprehensive financial plan makes individuals attentive when dealing with financial issues and acts as a guide when making financial decisions, underlying the consequences of those decisions on other financial areas (Botha, Du Preez, Geach, Goodall, Rossini \& Rabenowitz, 2012).

James, Leavell and Maniam (2002) opine that many households express no intent to save at all, choosing to rather avoid the many warning signs, such as the decreasing buying power of money, unemployment and increased financial 
risk that abound in the financial- and economic environment (Shim, Xiao, Barber \& Lyons, 2009). Students are no different from the rest of the population in this regard. Worryingly though, retirement planning, for the vast majority, ranks very low on their list of priorities, if it exists at all. Furthermore, individuals are reluctant to plan for the possibility of early retirement brought on by limited employment opportunities (Van Gijsen, 2002). Swart (2012) indicates that people, including students, take risks with their financial freedom either because they lack any understanding of the importance of financial management or because they simply choose to ignore financial matters because this makes them apprehensive. There is evidence that inadequate financial management ultimately results in high financial debt, severe credit card usage, high stress levels as well as low financial security (Sabri, MacDonald, Hira \& Masud, 2010). Therefore, managing financial resources should be a priority (Falahati, Paim, Ismail, Haron \& Masud, 2011).

Published literature on the South African Generation Y cohort's (individuals born between 1986 and 2005)(Markert, 2004; Eastman \& Liu, 2012) consumer behaviour is limited and none focuses specifically on this segment's attitudes towards personal financial planning. In the South African market, the African portion of this cohort (hereafter referred to as African Generation $Y$ ) is of particular interest to marketers and professionals, including those in financial institutions and those involved in financial management, especially financial planning, given that they represent 83 percent of this generational cohort (Statistics South Africa, 2013). As a tertiary qualification is generally associated with a higher earning potential and higher social standing within a community (Schiffman, Kanuk \& Wienblit, 2010; Bevan-Dye, Garnett \& De Klerk, 2012), those African Generation $Y$ university graduates are likely to be of particular interest to marketers of financial products and are also likely to act as role models amongst their peers. Therefore, the primary aim of the study reported on in this article was to determine African Generation Y students' attitudes towards personal financial planning and thereby address the gap in the literature.

\section{Literature Review}

\subsection{Personal financial management}

Personal financial management is concerned with managing personal finances through developing a strategic plan for productively managing an individuals or family unit's personal income, lifestyle expenditures and assets, and includes assisting them achieve their lifetime goals, taking into account various financial risks and future life events (Financial Planning Institute of South Africa, 2013b). Altfest (2004) states that personal financial management involves a process of managing financial resources in order to achieve personal economic satisfaction and indicates that because individuals move through different life cycle stages, which causes their goals and needs to evolve, personal financial management has become a self-motivated process. Boon, Yee and Ting (2011) maintain that financial freedom does not necessarily equate to great wealth but rather that individuals optimally utilise their income, irrespective of the level of that income.

Management, including personal financial management, is a process that consists of a continuous cycle of four core elements, namely planning, organising, leading and controlling (Robbins \& DeCenco, 2005). The planning component of personal financial management gives direction to an individual's finances, minimises risk and uncertainty, and aids in avoiding the need for crisis management. It involves setting measurable and attainable goals and developing strategies to achieve those goals (Van Rensburg, Meintjies, Kroon, Müller, Lancaster, Lessing \& Rankhumise, 2008). The organising process component of personal financial management commences once individuals have set financial goals and established strategies for achieving those goals. During this process, resources are allocated in a manner that allows for the execution of the planned strategies (Swart, 2012). Individuals should lead the management of their personal finances in such a way as to move towards future financial freedom (Banhegyi, Bosch, Botha, Booysen, Cunningham, Lotz, Musengi, Smith, Visser \& Williams, 2007). It is imperative that individuals control their financial resources by continuously comparing their financial objectives with the actual performance of their financial assets, specifically by being vigilant to any serious deviations resulting from unforeseen circumstances such as investment losses or a tax account in arrears (Van Rensburg et al., 2008).

Individuals and households should plan and manage their finances in order to avoid the burden of debt. Managing finances forms an integral part of all individuals' everyday lives, from students receiving bursaries or pocket money, to working individuals earning an income, to retired people receiving a monthly pension or retirement annuity payment. Successfully managing personal finances require not only having an understanding of certain financial concepts, but also knowing how to budget and being aware of the ratio between one's assets, savings and debt. A major hurdle in this regard is that many individuals have no formal training on how to manage their finances effectively (Botha \& Musengi, 2012). 


\subsection{Personal financial planning}

Most individuals falsely assume that personal financial planning is only for the affluent members of society. Personal financial planning should be a necessity for everyone, irrespective of their personal wealth. Notwithstanding this, individuals with a significant amount of financial resources are likely to benefit even more from personal financial planning, as it provides assistance on how to spend and invest prudently (Gitman \& Joehnk, 2008). According to Koh and Fong (2011), personal financial planning is a necessity if the individual desires to improve their standard of living, minimise their possibility of financial ruin, invest optimally and accumulate adequate wealth over time. Garman and Forgue (2008) state that being more astute regarding personal financial matters when facing the financial challenges, responsibilities and opportunities that life offers typically leads to several financial benefits. Examples of such benefits include marginal credit costs, reduced income taxes, better mortgage rates, lower insurance premiums and the like. In addition, financially astute individuals in more likely to make successful investment choices, better plan for their retirement and ensure that their estate is in order in the event of their death.

Swart (2012) defines personal financial planning as the organisation of an individual's financial and personal data for establishing a strategic plan to manage income, assets and liabilities in a constructive manner to satisfy short- and long-term goals and objectives. Understanding money matters and the financial management process are prerequisites for efficient personal financial planning (Boon et al., 2011). Efficient personal financial planning requires constantly trying to predict future events and paying attention to future financial needs as early as possible (Swart, 2009). Unfortunately, many individuals make personal financial decisions based purely on chance or on the informal advice of friends and/or family. Such a casual attitude towards money would include having a savings plan based simply on the surplus funds at the end of the month (Murphy \& Yetmar, 2010).

Globalised capital markets offer a constantly increasing diversity of financial products and investment opportunities, making personal financial planning an imperative to achieving personal financial goals (Boon et al., 2011). The development of an effective financial plan requires knowledge of the various personal financial planning areas, as each has potentially extensive positive and negative financial repercussions (Swart, 2012). Whilst the areas of financial planning include career planning, income tax planning, estate planning, investment planning, insurance planning, credit planning, retirement planning project planning, family planning, productivity planning, emigration planning and business planning (Cooper \& Worsham, 2002; Warschauer, 2002; Lai \& Tan, 2009; Swart, 2012), this study only focused on credit, insurance, investment, retirement and estate planning.

Credit planning involves prudently and purposefully incurring debt for the purpose of satisfying individual needs and achieving financial goals, while simultaneously managing cash inflows and outflows. This necessitates the development of a personal financial budget (Swart, 2012). Credit planning strategies include paying off loans, overdrafts, store and credit cards with the highest interest rate first, as well as selling non-essential assets or liquidating investments to settle debts such as mortgage bonds in order to benefit from early payment cost of capital savings (Botha et al., 2012). In summary, credit planning relates to moderation, affordability and the management of debt to avoid long-term negative consequences.

Insurance planning is the process of recognising, investigating and prioritising risks, followed by the process of employing strategies to mitigate, monitor and control the likelihood and/or consequence of unfortunate occurrences (Botha, Du Preez, Geach, Goodall, Palframan, Rossini \& Rabenowitz, 2011). Insurance-related risks are planned by employing several strategies, such as risk avoidance (actions taken to avoid risky financial circumstances), risk reduction (actions taken to alleviate exposure to financial risks) and risk transference (purchasing short- and long-term insurance are recognised methods of transferring risks) (Botha et al., 2012). In insurance planning, it is important to balance the risk and the cost of insuring against the risk.

Investment planning is the utilisation of funds with the intention of earning an income from those funds (Swart, 2012). Prior to making an investment decision, individuals need to consider their short-, medium- and long-term financial goals, financial risks (such as death or disease) and financial needs (such as a life policy or medical scheme/insurance). Thereafter, they need to be able to evaluate and compare different investments and be knowledgeable on the different types of investment options available (Swart, 2009). Swart (2012) emphasises that investment planning is one of the principal areas of personal financial planning because it is a fundamental part of retirement planning, has a direct influence on safeguarding future financial well-being and is important for the achievement of short-, medium- and longterm goals.

Retirement planning is more complex than merely contributing to a pension, provident or retirement annuity fund, as it requires knowledge of tax laws, compound interest, present and future time value of money, and investment strategy (Botha et al., 2012). Retirement planning is about saving an amount of money whilst working in order to provide an 
income after retirement (Van Gijsen, 2002). The sooner an individual starts planning and saving for retirement, the greater the amount that will be available for retirement This suggests that individuals should invest as much as possible, as soon as possible and for as long as possible (Biehler, 2008). Swart (2012) proposes three steps when planning for retirement. First, establish retirement goals, such as maintaining an equal standard of living as before retirement. Secondly, establish an amount of money required to attain the set goals. This amount is determined by assessing the expenses and income during retirement. Lastly, prepare an investment portfolio within the constraints of the personal financial budget.

Estate planning involves the organisation, management and securement, and disposition of an individual's estate so that the individual, his/her family, and other heirs may benefit and continue to benefit to the maximum from the individual's estate and assets during the individual's lifetime and after death, irrespective of when death may occur (Botha et al., 2012). Comprehensive estate planning requires timely planning (during the estate owner's life), testamentary planning (in the individual's will) and other planning (such as insurance planning). Estate planning is a continuous process and consists of two phases, as indicated by Botha et al. (2011). The first phase of the estate planning process concerns planning during the individual's life and includes preserving the value of an estate at its present value to attain estate duty and capital gains tax savings, while at the same time ascertaining that minimum liquidity difficulties arise. After the death of the individual, the second phase of the estate planning process commences, and involves the implementation of the provisions of the will of the individual.

Swart (2012) explains that personal financial planning has an effect on all individuals and with knowledge of basic financial issues, individuals can take responsibility for a promising financial future that enables the transference of skills to others especially their children, guaranteeing a positive financial future for the younger generation. Worryingly though is that, according to a study done by the ANZ Banking Group in Australia and New Zealand, 37 percent of the participants (adults aged between 18 and 70 years and older) do not know the amount of money needed to fund a comfortable retirement (Louw, 2009). According to Swart (2012), less than one out of every ten individuals in South Africa is financially independent when retiring. These statistics are suggestive of the reality that most individuals do not know what personal financial planning involves or how to embark on such planning.

\subsection{Generation $Y$}

In generational studies, the youth are labelled as Generation $Y$ and is classified as those individuals born between 1986 and 2005 (Markert, 2004; Eastman \& Liu, 2012), which, in 2013, puts them at nine to 28 years of age. South Africa's population totalled around 52981991 in 2013, of which an estimated 38 percent formed part of the Generation Y cohort. In terms of race, the African portion of this Generation $Y$ cohort accounted for approximately 83 percent of the South African Generation $Y$ cohort and 32 percent of the total South African population (Statistics South Africa, 2013). Cui, Trent, Sullivan and Matiru (2003) claim that Generation $Y$ is widely considered the next big generation with powerful aggregate spending. Cox, Kilgore, Purdy and Sampath (2008) opine that Generation Y members are positioned to become the wealthiest generation thus far. Furthermore, the financial appetite of Generation $Y$ is growing owing to the fact that more members own a cheque account and a credit card.

According to Shaw and Fairhurst (2008) and Schlitzkus, Schenarts and Schenarts (2010), the Generation Y cohort were the first generation exposed to the Internet, mobile phones, convergent technologies and various multimedia platforms, including computer-generated social media networks such as Facebook, computer-generated social reporting such as Twitter and computer-generated social media such as YouTube. Given the size of the Generation Y market and its member's tendency to utilise technology to manage personal finances, financial institutions must start planning for the future. Technologically-innovative financial institutions that take advantage of technology that connects with Generation $Y$ in ways with which the members are familiar with, such as online messaging, social networking and targeted offerings to mobile phones, will be successful in their dealings with Generation Y (Cox et al., 2008; Constantine, 2010). Robson (2012) concur that technology will act as a catalyst in creating a differentiating experience for Generation $Y$ in managing personal finances.

As highlighted by Bevan-Dye and Surujlal (2011) and Bevan-Dye et al. (2012), Generation Y, in particular South Africa's African Generation Y members, are viewed as being optimistic, self-assured, education-directed and highly motivated individuals. It is essential that this generation engage in personal financial planning and management to secure a stable financial future. Unfortunately, these members, as indicated by Borden, Lee, Serido and Dawn (2008), have more lenient attitudes towards debt, meaning that debt instalments would possibly increase. Moreover, one could infer that this Generation Y cohort would have positive attitudes to the use and misuse of credit cards. Generation $Y$ face the challenge of making financial decisions in an increasingly complex financial environment and, therefore, the management 
of finances in all areas of personal financial planning should be improved (Cudmore, Patton, $\mathrm{Ng} \&$ McClure, 2010).

\section{Methodology}

This study adopted a quantitative approach to determine African Generation $Y$ students' attitudes towards personal financial planning.

\subsection{Sample}

For this study, the target population was defined as full-time undergraduate African Generation $Y$ students, aged between 18 and 24 years, registered at South African higher education institutions (HEIs) in 2013. From the sampling frame of the 23 registered South African public HEls in 2013 (Higher Education in South Africa, 2013), a judgement sample of two HEls campuses located in the Gauteng province was selected, one from a traditional university and the other from a university of technology. A non-probability convenience sample of 500 African Generation $Y$ full-time undergraduate students was then drawn from these two campuses.

\subsection{Measurement instrument and data collection procedure}

A structured self-administered questionnaire was utilised to gather the required data. This questionnaire included an existing scale from previously published research. The Boon et al. (2011) Financial Planning Scale was adapted and used to measure African Generation Y students' attitudes towards personal financial planning in the South African context. This 30-item scale comprises six constructs, namely the financial planning process (five items), credit planning (five items), insurance planning (five items), investment planning (eight items), retirement planning (three items) and estate planning (three items). Responses were measured on a six-point Likert scale (1= strongly disagree, 6= strongly agree). The questionnaire included a section designed to gather relevant demographical data from the participants. In addition, the questionnaire was accompanied by a cover letter explaining the purpose of the study and requesting participation from the students.

The questionnaire was piloted on a convenience sample of 40 students on a South African HEI campus that did not form part of the sampling frame, in order to ascertain reliability. The scale returned a Cronbach alpha value of 0.699 , which are within the recommended Cronbach alpha level of 0.6 (Malhotra, 2010). The questionnaire was then administered to the identified sample. Lecturers at each of the two HEls were contacted and asked if they would allow the questionnaire to be distributed to their students either during class or after class. Once permission had been obtained, fieldworkers distributed the questionnaire to students at the two campuses, who were duly informed that participation was on a voluntary basis only.

\section{Results}

\subsection{Sample characteristics}

Of the 500 questionnaires distributed, 385 completed and usable questionnaires were returned. The majority of the participants in the sample indicated being 21 years of age, followed by those who indicated being 20 years of age and 19 years of age. The sample comprised more female participants than male participants. Concerning the participants' year of study, the majority indicated being first-year students, followed by those who indicated that they were in their third- and second year. With the exception of the Western Cape, each of South Africa's provinces was represented, with the majority of participants indicated Gauteng as their province of origin, followed by Limpopo. Table 1 provides the demographic information of the sample's participants. 
Table 1. Sample description

\begin{tabular}{|c|c|c|c|c|c|c|c|c|c|}
\hline Age & $\mathbf{N}(\%)$ & Gender & $\mathbf{N}(\%)$ & Year of study & $\mathrm{N}(\%)$ & Province of origin & $\mathbf{N}(\%)$ & Institution & $\mathrm{N}(\%)$ \\
\hline 18 & $40(10)$ & Male & $144(37)$ & First year & $161(42)$ & Eastern Cape & $7(2)$ & HEl A & $208(54)$ \\
\hline 19 & $79(21)$ & Female & 241 (63) & Second year & $94(24)$ & Free State & 36 (11) & HEI B & $177(46)$ \\
\hline 20 & $94(24)$ & & & Third year & $130(34)$ & Gauteng & $196(60)$ & & \\
\hline 21 & $120(31)$ & & & & & KwaZulu-Natal & $11(3)$ & & \\
\hline \multirow[t]{4}{*}{22} & $52(14)$ & & & & & Limpopo & 37 (11) & & \\
\hline & & & & & & Mpumalanga & $21(7)$ & & \\
\hline & & & & & & Northern Cape & $3(1)$ & & \\
\hline & & & & & & North-West & $15(5)$ & & \\
\hline
\end{tabular}

\subsection{Reliability and validity}

In the main survey, an acceptable Cronbach alpha value of 0.820 was computed for the overall Financial Planning Scale. The Cronbach alphas of the individual constructs ranged between 0.289 for retirement planning, 0.524 for credit planning, 0.628 for investment planning, 0.711 for both insurance planning and financial planning and 0.817 for estate planning. The retirement planning construct was excluded from further analysis given its unacceptably low Cronbach alpha value. An assessment of the credit card planning construct determined that the deletion of two items (convenience of credit cards and personal loans) would increase the Cronbach alpha to an acceptable 0.736 level. Following the removal of these two items, the average inter-item correlation values of each construct were computed in order to assess the construct validity of the scale. The average inter-item correlation coefficients for each of the five remaining construct all fell within the recommended range of 0.15 and 0.50 , thereby suggesting both convergent and discriminant validity (Clark \& Watson, 1995).

\subsection{One sample t-test}

Means above 3 were computed for all five constructs in the attitudes towards Personal Financial Planning Scale. In order to evaluate whether these calculated means were statistically significant, a one-tailed one-sample t-test was conducted. The level of significance was set at the typical $0.05(\alpha=0.05)$ and the expected mean was set at mean $>3$. As reported on in Table 2, significant $p$-value ( $p=0.000<0.05)$ were computed for the five constructs of personal financial planning, indicating statistical significance. This infers that African Generation $Y$ students do exhibit a statistically significant positive attitude towards the financial planning process, credit planning, insurance planning, investment planning and estate planning. Table 2 presents the computed means, standard deviations, standard errors, t-values and p-values.

Table 2. African Generation Y students' attitudes towards personal financial planning

\begin{tabular}{|c|c|c|c|c|c|}
\hline Financial planning constructs & Mean & $\begin{array}{l}\text { Standard } \\
\text { deviation }\end{array}$ & $\begin{array}{c}\text { Standard } \\
\text { error }\end{array}$ & $\begin{array}{c}\mathrm{t}- \\
\text { values }\end{array}$ & $\begin{array}{c}\text { P. } \\
\text { values }\end{array}$ \\
\hline Financial planning process & 3.948 & 0.921 & 0.046 & 20.192 & $0.000^{*}$ \\
\hline Know what personal financial planning is & 4.745 & 1.064 & 0.054 & 32.176 & $0.000^{*}$ \\
\hline Set personal financial goals and objectives & 4.483 & 1.277 & 0.065 & 22.790 & $0.000^{*}$ \\
\hline $\begin{array}{l}\text { Gather relevant data and analyse current financial position before making a } \\
\text { financial decision }\end{array}$ & 4.236 & 1.466 & 0.075 & 16.546 & $0.000^{*}$ \\
\hline Implement a personal financial plan with the help of experts & 2.481 & 1.429 & 0.073 & -7.133 & $0.000^{*}$ \\
\hline $\begin{array}{l}\text { Review the financial plan regularly to take into account changing needs and } \\
\text { circumstances }\end{array}$ & 3.792 & 1.479 & 0.075 & 10.514 & $0.000^{*}$ \\
\hline Credit planning & 4.187 & 1.282 & 0.065 & 18.156 & $0.000^{*}$ \\
\hline Pay off full outstanding amount on accounts every month & 3.922 & 1.688 & 0.086 & 10.721 & $0.000^{*}$ \\
\hline Pay all accounts on time each month & 4.094 & 1.572 & 0.080 & 13.651 & $0.000^{*}$ \\
\hline Avoid maxing out or going over the limit on accounts & 4.545 & 1.491 & 0.076 & 20.341 & $0.000^{*}$ \\
\hline Insurance planning & 4.227 & 1.001 & 0.051 & 24.051 & $0.000^{*}$ \\
\hline List needs for life insurance & 3.657 & 1.567 & 0.080 & -8.229 & $0.000^{*}$ \\
\hline Comparison shopping for life insurance & 3.462 & 1.508 & 0.077 & 6.014 & $0.000^{*}$ \\
\hline Plan to have enough life insurance & 4.706 & 1.579 & 0.081 & 21.201 & $0.000^{*}$ \\
\hline Life insurance is the most important type of insurance & 4.943 & 1.332 & 0.068 & 28.632 & $0.000^{*}$ \\
\hline Distinguish the different types of insurance policies & 4.366 & 1.346 & 0.069 & 19.921 & $0.000^{*}$ \\
\hline
\end{tabular}




\begin{tabular}{llllll}
\hline Investment planning & 4.551 & 0.717 & 0.036 & 42.441 & $0.000^{*}$ \\
\hline Importance of investing & 5.499 & 0.982 & 0.050 & 49.930 & $0.000^{*}$ \\
Investment plan for reaching financial goals & 4.114 & 1.557 & 0.079 & 14.042 & $0.000^{*}$ \\
Consider the opinion of friends and/or family before investing & 3.966 & 1.598 & 0.081 & 11.864 & $0.000^{*}$ \\
Understand risk profile & 4.457 & 1.326 & 0.068 & 21.556 & $0.000^{*}$ \\
Invest in different investment instruments with minimal knowledge and research & 4.112 & 1.635 & 0.083 & 13.343 & $0.000^{*}$ \\
Compound interest encourages investing & 4.403 & 1.312 & 0.067 & 20.983 & $0.000^{*}$ \\
Knowledge to invest & 4.688 & 1.322 & 0.067 & 25.068 & $0.000^{*}$ \\
Study alternatives carefully before investing & 5.177 & 1.005 & 0.051 & 42.488 & $0.000^{*}$ \\
\hline Estate planning & 5.142 & 0.889 & 0.045 & 47.275 & $0.000^{*}$ \\
\hline Importance of having a will & 5.299 & 1.081 & 0.055 & 41.728 & $0.000^{*}$ \\
Importance of estate planning & 5.171 & 1.110 & 0.057 & 38.402 & $0.000^{*}$ \\
Importance of setting up a family trust as part of estate planning & 5.075 & 1.062 & 0.054 & 38.356 & $0.000^{*}$ \\
Having estate planning will give peace of mind when passing away & 5.026 & 1.172 & 0.059 & 33.909 & $0.000^{*}$ \\
\hline * Significant at p p 0.05 (one-tailed) & & & & &
\end{tabular}

An independent-samples t-test was conducted to compare the personal financial planning mean scores of males and females. As is evident in Table 3, significant differences were found between males and females concerning the financial planning process $(p=0.006<0.05)$ and investment planning construct $(p=0.031<0.05)$. For both the financial planning process and investment planning, males scored significantly higher. This suggests that, in comparison to their female counterparts, African Generation Y students take financial planning and investment planning more seriously. There were no significant differences between males and females' attitudes towards credit planning, investment planning and estate planning. The results are reported on in Table 3.

Table 3. Gender differences on attitudes towards personal financial planning

\begin{tabular}{lcccccc}
\hline & \multicolumn{2}{c}{ Male } & \multicolumn{2}{c}{ Female } & \\
\hline Construct & $\begin{array}{c}\text { Mean } \\
\boldsymbol{n}=\mathbf{1 4 4}\end{array}$ & Standard deviation & $\begin{array}{c}\text { Mean } \\
\boldsymbol{n}=\mathbf{2 4 1}\end{array}$ & Standard deviation & \multirow{2}{*}{ t-values } & P-values \\
\hline Financial planning process & 4.115 & 0.881 & 3.847 & 0.932 & 2.786 & $0.006^{*}$ \\
Credit planning & 3.746 & 0.878 & 3.659 & 1.024 & 1.514 & 0.131 \\
Insurance planning & 4.269 & 1.007 & 4.202 & 0.999 & 0.642 & 0.521 \\
Investment planning & 4.654 & 0.623 & 4.491 & 0.763 & 2.160 & $0.031^{\star}$ \\
Estate planning & 5.142 & 0.845 & 5.143 & 0.917 & -0.008 & 0.993 \\
\hline
\end{tabular}

* Statistically significant at $p<0.05$

\section{Discussion}

This study investigated African Generation Y students' attitudes towards personal financial planning in terms of the financial planning process, credit planning, insurance planning, investment planning and estate planning in South Africa. In order to evaluate students' attitudes towards personal financial planning, this study used the Financial Planning Scale of Boon et al. (2011). The results of this study provide valuable insights into the attitudes of African Generation Y students towards personal financial planning. The findings of the study suggest that African Generation $Y$ students have a positive attitude towards personal financial planning. This positive attitude, coupled with the significant size of the African Generation $Y$ cohort and the future higher earning potential of role model status of graduates make African Generation $Y$ students an important target segment for a range of financial institutions, including banks, insurance companies, investment companies, and the like. Given that this generational cohort are known to be technologically astute and comfortable using online and mobile communication, financial institutions should incorporate new digital platforms to reach this target segment. Establishing a Facebook page and designing mobile telephone advertisements that appeal specifically to this ethnic and age cohort, whether it be in terms of the music and visual copy or even the use of a local African celebrity, will help financial institutions engage better with this segment. In this regard, many financial institutions are in the process of trying to move their customers online, and this cohort are likely to be much easier to convert to such technological advancements as online trading, mobile banking and online credit card and loan applications.

Students' attitudes towards estate planning were ranked the highest, suggesting that African Generation $Y$ students perceive this construct to be the most important part of financial planning. Students find it important to have a will and that estate planning is essential. Investment planning was ranked the second highest suggesting that students 
perceive investment as essential in personal financial planning. The evidence in the sample suggests that students consider investing as important and will carefully evaluate the different investment alternatives available before investing. Furthermore, considering the opinion of friends and/or family before investing ranked the lowest in this construct. Insurance planning was ranked the third highest indicating that students perceive insurance as valuable. The evidence in the sample suggests that students find life insurance essential as well as planning to have sufficient life insurance. Credit planning ranked the fourth highest construct with avoiding mixing out or going over the limit on their accounts ranked the highest in this construct followed by paying their accounts on time. Students' attitudes towards the financial planning process were ranked the lowest, suggesting less positive attitudes towards the financial planning process. The evidence in the sample suggest that although students indicated knowing what personal financial planning is and having positive attitudes towards setting personal financial goals and objectives, they do not implement a personal financial plan with the help of experts.

The results of this study suggest attitude differences pertaining to the financial planning process and investment planning between male and female students. As such, financial institutions should appeal differently to males and females when marketing financial products and services. Advertisements depicting strong independent African women managing their own personal finances and making their own investment decisions may help to make African Generation $Y$ female students more aware of the importance of taking charge of their own future financial well-being.

Like most studies, several limitations can be identified within this study, consequently presenting several opportunities for future research. Within this study, a non-probability convenience sampling approach was applied to survey the study's participants. Therefore, there is a necessity to take care in interpreting the results. Furthermore, the study lacks the accurateness of a longitudinal study since this study made use of a single cross-sectional design. Given the dearth of research conducted on the consumer behaviour of the African Generation Y cohort in South Africa, especially related to personal finance, future research in this area is recommended.

\section{Conclusion}

In an economy characterised by high interest rates, inflation, unemployment, political instability and various other economic downfalls, individuals' money matters are constantly under threat. Personal financial management, with reference to personal financial planning, is a recognised intervention to secure a promising and stable financial standing, in both the short- and long-term, and may combat the adverse effects of these economic factors. The Generation $Y$ consumer, especially the African Generation $Y$ consumer, is regarded as the future of South Africa and their attitude towards personal finance is expected to shape the continually changing financial and economic environment, especially concerning personal financial management. The findings of this study indicate that African Generation $Y$ students have significant positive attitudes towards personal financial planning. Through better understanding students' financial management, the results of this study may aid in creating awareness of certain shortfalls in African Generation $Y$ students' personal financial management. This in turn will aid financial institutions and professionals in gauging effective ways to convey financial knowledge and product information to this target market to deliver improved financial service. This is likely to benefit the nation as a whole. Industry professionals, including financial institutions and those involved in financial management, especially in financial planning, are advised to consider the student portion of this age and ethnic cohort in particular given that African Generation $Y$ students with a tertiary education are likely to manifest as pertinent opinion leaders and financial trendsetters amongst their peers.

\section{References}

Alffest, L. (2004). Personal financial planning: origins, development and a plan for future direction. The American Economist, 48(2), 5360.

Banhegyi, S., Bosch, A., Botha, S., Booysen, K., Cunningham, P., Lotz, O., Musengi, S., Smith, A.S., Visser, K. \& Williams, O. (2007). Management: fresh perspectives. Cape Town: Pearson.

Bevan-Dye, A.L., Garnett, A. \& De Klerk, N. (2012). Materialism, status consumption and consumer ethnocentrism among black generation Y students in South Africa. African Journal of Business Management, 6(16), 5578-5586.

Bevan-Dye, A.L. \& Surujlal, J. (2011). Attitudes towards materialism in sport and materialism tendencies amongst Black Generation Y students. African Journal for Physical, Health Education, Recreation and Dance, Supplement, 17(4), 43-55.

Biehler, T.J. (2008). The mathematics of money: math for business and personal finance decisions. New York: McGraw-Hill.

Boon, T.H., Yee, H.S. \& Ting, H.W. (2011). Financial literacy and personal financial planning in Klang Valley, Malaysia. International Journal of Economics and Management, 5(1), 149-168.

Borden, L.M., Lee, S., Serido, J. \& Dawn, C. (2008). Changing college students' financial knowledge, attitudes and behaviour through 
seminar participation. Journal of Family Economics, 29(1), 23-40.

Botha, M., Du Preez, L., Geach, W., Goodall, B., Palframan, J., Rossini, L. \& Rabenowitz, P. (2011). Fundamentals of financial planning 2012. Durban: LexisNexis.

Botha, M., Du Preez, L., Geach, W., Goodall, B., Rossini, L. \& Rabenowitz, P. (2012). The South African financial planning handbook 2012. Durban: LexisNexis.

Botha, S. \& Musengi, S. (2012). Introduction to business management: fresh perspectives. Cape Town: Pearson.

Chinen, K. \& Endo, H. (2012). Effects of attitude and background on students' personal financial ability: a United States survey. International Journal of Management, 29(2), 778-791.

Clark, L.A. \& Watson, D. (1995). Constructing validity: basic issues in objective scale development. Psychological Assessment, 7(3), 309-319.

Constantine, Greg. (2010). Tapping into Generation Y: nine ways community financial institutions can use technology to capture young customers. [Online] Available: http://www.firstdata.com/downloads/thought-leadership/geny_wp.pdf (February 14, 2013).

Cooper, Robert.W. \& Worsham, C.Bruce. (2002). The financial planning process. [Online] Available http://www.docstoc.com/docs /38716987/The-Financial-Planning-Process---PDF (April 4, 2013).

Cox, David., Kilgore, Thomas.L., Purdy, Tiffany. \& Sampath, Rekha. (2008). Catalysts for change: the implications of Gen Y consumers for banks. [Online] Available http://www.deloitte.com/assets/Dcom-Shared\%20Assets/Documents/us_fsi_GenY_ Consumers_ april08.pdf (February 14, 2013).

Cudmore, B.A., Patton, J., Ng, K. \& McClure, C. (2010). The millennials and money management. Journal of Management and Marketing Research, 4(1), 1-28.

Cui, Y., Trent, E.S., Sullivan, P.M. \& Matiru, G.N. (2003). Cause-related marketing: how Generation Y responds. International Journal of Retail and Distribution Management, 31(6), 310-320.

Eastman, J.K. \& Liu, J. (2012). The impact of generational cohorts on status consumption: an exploratory look at generational cohort and demographics on status consumption. Journal of Consumer Marketing, 29(2), 93-102.

English, J., Hicks, B., Hrasky, S. \& Gyles, N. (2003). Personal financial management. Australia: Griffin Press.

Falahati, L., Paim, L., Ismail, M., Haron, S. \& Masud, J. (2011). Assessment of university students' financial management skills and educational needs. African Journal of Business Management, 5(15), 6085-6091.

Financial Planning Institute of South Africa. (2013a). Plan first before you invest. [Online] Available https://www.fpi.co.za/Article Detail/tabid/3716/language/en-ZA/Default.aspx?Aid=99 (April 4, 2013).

Financial Planning Institute of South Africa. (2013b). Realise your financial dreams: it all starts with a plan by Prof. Dilip Garach, CFP, FPI financial planner of the year, 2004. [Online] Available http://www.fpi.co.za/NewsArticles/tabid/3717/ArticleID/33/language/enZA/Default.aspx (April 4, 2013).

Garman, E.T. \& Forgue, R.E. (2008). Personal finance. (9th ed.). USA: Cengage Learning.

Gitman, L.J. \& Joehnk, M.D. (2008). Personal financial planning. New York: South-Western Thompson Learning.

Higher education in South Africa. (2013). [Online] Available http://www.southafricaweb.co.za/page/higher-education-south-africa (July 20, 2013).

James, J., Leavell, H.W. \& Maniam, B. (2002). Financial planning, managers and college students. Managerial Finance, $28(7), 35-42$.

Koh, B. \& Fong, W.M. 2011. Personal financial planning. (4th ed.). Singapore: Prentice Hall.

Kolb, B. (2008). Marketing Research: a practical approach. London: Sage.

Lai, M.M. \& Tan, W.K. (2009). An empirical analysis of personal financial planning in an emerging economy. European Journal of Economics, Finance and Administrative Sciences, (16), 99-111.

Louw, J.J. (2009). Financial literacy competencies of third-year university students: a case study. North-West University, Masters Dissertation.

Louw, J., Fouchè. J. \& Oberholzer, M. (2013). Financial literacy needs of South African third-year university students. International Business and Economics Research Journal, 12(4), 439-450.

Malhotra, N.K. (2010). Marketing research: an applied orientation. (6th ed.). New Jersey: Prentice Hall.

Markert, J. (2004). Demographics of age: generational and cohort confusion. Journal of Current Issues and Research in Advertising, 26(2), 11-25.

Mazzucato, M., Lowe, J., Shipman, A. \& Trigg, A. (2010). Personal investment: financial planning in an uncertain world. New York: Palgrave MacMillan.

Murphy, D.S. \& Yetmar, S. (2010). Personal financial planning attitudes: a preliminary study of graduate students. Management Research Review, 33(8), 811-817.

Nunally, J. (1978). Psychometric theory. (2nd ed.). New York: McGraw-Hill.

Pallant, J. (2007). SPSS Survival manual. London: Open University Press.

Peterson, R.A. (1994). A meta-analysis of Cronbach's coefficient alpha. Journal of Consumer Research, 21(2), 381-391.

Robbins, J.A. \& DeCenco, D.A. (2005). Fundamentals of management: essential concepts and applications. (5th ed.). New York: Prentice Hall.

Robson, Sophie. (2012). Generation Y: the (modern) world of personal finance. [Online] Available http://www.thefinancialfairytales.com /blog/wp-content/uploads/2012/07/Generation_Y...by_Sophie_Robson_PDF.pdf (February 14, 2013).

Rutherford, L.G. \& Fox, W.S. (2010). Financial wellness of young adults age $18-30$. Family and Consumer Sciences Research Journal, $38(4), 468-484$ 
Sabri, M.F., MacDonald, M., Hira, T.K. \& Masud, J. (2010). Childhood consumer experience and the financial literacy of college students in Malaysia. Family and Consumer Sciences Research Journal, 38(4), 455-467.

Schiffman, L.G., Kanuk, L.R. \& Wisenblit, J. (2010). Consumer behavior. (10th ed.). New Jersey: Prentice Hall.

Schlitzkus, L.L., Schenarts, K.D. \& Schenarts, P.J. (2010). Is your residency program ready for Generation Y? Journal of Surgical Education, 67(2), 108-111.

Shaw, S. \& Fairhurst, D. (2008). Engaging a new generation of graduates. Education + Training, 50(5), 366-378.

Shim, S., Xiao, J.J., Barber, B.L. \& Lyons, A.C. (2009). Pathways to life success: a conceptual model of financial well-being for young adults. Journal of Applied Development Psychology, 30(6), 708-723.

Statistics South Africa. (2013). Mid-year population estimates: 2013 key indicators, Statistical release P0302. [Online] Available http://www.statssa.gov.za (August 16, 2013).

Swart, N. (2009). Manage your money: basic financial life skills for South Africans. (2nd ed.). Pretoria: Van Schaik.

Swart, N. (2012). Personal financial management: the Southern African guide to personal financial planning. (3rd ed.). Claremont: Juta.

Van Gijsen, N. (2002). Retirement - all you want to know without the jargon. Cape Town: Pearson.

Van Rensburg, L.R.J., Meintjes, A., Kroon, J., Müller, C., Lancaster, M., Lessing, K. \& Rankhumise, E. (2008). Business management: an introduction. (2nd ed.). Pretoria: Van Schaik.

Warschauer, T. (2002). The role of universities in the development of the personal financial planning profession. Financial Services Review, 11(3), 201-216. 